\title{
Morangos Silvestres sob a Luz dos Devaneios Poéticos da Casa Onírica Bachelardiana...
}

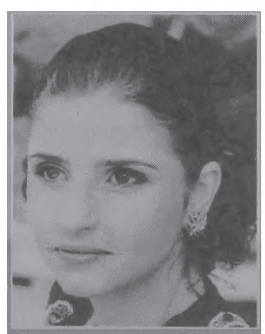




\section{Resumo}

Este artigo se propõe a fazer uma leitura do filme Morangos Silvestres de Ingmar Bergman com base na concepção fenomenológica de Gaston Bachelard em La Poétique de l'Espace.

Palavras-chave

cinema, poética, espaço.

\section{Abstract}

The goal of this article is a reading of the film Smultronstállet by Ingmar Bergman based on the concept of phenomenology discussed by Gaston Bachelard in his book La Poétique de l'Espace.

\section{Key words}

cinema, poetics, space 
Fa^erfilmes é também mergulhar até as mais profundas raizes, até o mundo da infância. INGMAR BERGMAN

\section{Introdução}

Com toda a imprudência de uma primeira leitura, escrevo sob a influência de um Racbelard que não conheço...

esta breve introdução, gostaria de escrever um pouco a respeito de minhas impressões iniciais a respeito de Bachelard, que tem me enfeitiçado cada vez mais. As sensações que vim tendo ao longo das leituras fizeram-me lembrar um trecho de Oscar Wilde:

Era um livro cheio de veneno. Um odor pesado de incenso parecia aderir-se às páginas e transformar o cérebro. A simples cadência das frases, a monotonia suitil de uma música tão cheia de complexos estribilhos e de movimentos sabiamente repetidos produziam no espírito do jovem, enquanto avançava de capítulo em capítulo, uma espécie de devaneio, de sonho doentio, que não o deixava perceber que entardecia e que as sombras invadiam furtivamente o aposento (WILDE, 1972, p. 153). 
Embora a descrição pareça a da leitura de um fabuloso livro de poesias ou um romance, e de Bachelard escrever inúmeras vezes que o trabalho de um filósofo não consegue ter uma intensidade poética de devaneio comparável à dos poetas, creio que somente alguns poucos romances me fizeram devanear em torno da escrita de um escritor com a mesma profundidade que o fez Bachelard.

Outra observação inicial é que o cineasta que "pretendo descobrir" à luz bachelardiana é Ingmar Bergman, diretor capaz de contemplar com suas poderosas imagens um mundo tão universal e ao mesmo tempo tão particular (na perspectiva de uma dialética do interior e do exterior).

Bachelard e Bergman, mas o quê?

De Bachelard, entre algumas outras coisas, A poética do espaço, livro que diz:

Um filósofo que formou todo o pensamento atendose aos temas fundamentais da filosofia das ciências, que seguiu o mais exatamente possivel a linha do racionalismo ativo, a linha do racionalismo crescente da ciência contemporânea, deve esquecer o seu saber, romper todos os hábitos de pesquisas filosóficas, se quiser estudar os problemas propostos pela imaginação poética. Aqui o passado cultural não conta; o longo trabalho de relacionar e construir pensamentos, trabalho de semanas e meses, é ineficaz. É necessário estar presente, presente ò imagem no minuto da imagem: se há uma filosofia da poesia, ela deve nascer e renascer por ocasião de um verso dominante, da adesão total a uma imagem isolada, muito precisamente no êxtase da novidade da imagem (Bàchelard, 1989, p. 1).

Significação $13 \quad 48$ 
De Bergman, Morangos silvestres, que, entre outras coisas, nos remete à questão da casa onírica, que é um dos principais temas de discussão do livro de Bachelard. Além disso, acredito que para podermos fazer uma incursão baseada nos princípios fenomenológicos de Bachelard - a não ser que seja para demonstrar uma falta de embasamento material é necessário uma obra que tenha suficiente profundidade poética e metafísica para enriquecer a argumentação.

A partir destas duas obras, decidi fazer uma abordagem em contraponto, isto é, por um lado tomarei o relato do filme, seguindo a ordem das seqüências, e por outro as sugestões de Bachelard; além disso, também farão parte desta mesma abordagem o contraponto entre reproduções de fotogramas e citações do autor, tentando assim reunir tanto a proposta de estudara "fase noturna"1 de Bachelard, o Bachelard poético, quanto o Cinema. Claro que tudo isso não passa de um pretexto para entrar em dois mundos intensamente, profundamente, alucinadamente poéticos. Sem a necessidade de paliativos da ordem das drogas, talvez apenas com "uma pequena loucura experimental, como um grão de haxixe virtual, sem cuja ajuda não podemos entrar no reino da imaginação" (BACHELARD, 1989, p. 222).

Poder devanear junto as estes dois "bem feitores da humanidade" é, incontestavelmente, um grande privilégio. Nem todos os trajetos me trazem tantas alegrias, o próprio fato de estar escrevendo já é uma espécie de sofrimento, um sofrimento saudável. "Para escrever um livro é preciso refletir" (BACHELARD, 1 989, p. 22), para escrever um trabalho, ainda que pequeno, também.

1. Como definiu José Américo Motta Pessanha em seu prefácio à obra $\mathrm{O}$ direito de sonhar de Bachelard (1985). 


\title{
A Viagem
}

\author{
Nada mais aconchegante que o silêncio, uma \\ candeia, um bom livro e um cálice de vinho...
}

Para iniciar a incursão, tentarei expor, através de alguns fragmentos de textos bachelardianos, alguns possíveis devaneios poéticos que possam ter levado Bergman a desenvolver o roteiro de $\mathrm{A}^{\wedge}$ lorangos silvestres.

[...] por ocasião de uma viagem de carro a Uppsala, de manhã, bem cedo [...] fui tomado pelo desejo de visitar a velha casa onde vivera minha avó, na Tràdgardsgatan (Rua do Jardim). Como permaneci do lado de fora da porta de entrada para a cozinha e, num instante mágico, senti a possibilidade de regressará minha infância. Claro que isso é uma mentira inocente. A verdade pura e nua é que vivo continuamente na minha infância, passeio pelas silenciosas ruas de Uppsala, vejo-me diante da casa de veraneio e escuto o murmúrio da folhagem da bétula gigantesca que ali havia. Desloco-me a uma velocidade incrivel, pois no fundo vivo permanentemente em meu sonho e faço visitas à realidade.

[...]

A força motora de Morangos silvestres é [...] uma tentativa desesperada de me justificar perante meus pais que me voltaram as costas e a quem dera dimensões desproporcionadas, míticas, tentativa esta de estar condenada a falhar [...] (BERGMAN, 1996,

p. 21-2). 
Suponho que um dos motivos mais fortes que se esconde atrás de Morangos silvestres está justamente nisso. Eu fazia uma idéia da minha pessoa a partir da pessoa que meu pai era e procurava uma explicação para os conflitos acérrímos que tinha com minha mãe. Percebia que eu fora um filho não desejado, parido durante uma crise psíquica de minha mãe.

Seus diários confirmaram, mais tarde, minhas suposições: perante o filho que teve, e que quase morreu de debilidade, minha mãe revelou uma terrivel atitude ambivalente (BERGMAN, 1996, p. 17 e 20).

Com estas introduções que abordam um lado mais psicológico da personalidade de Bergman e do roteiro deMorangos silvestres, não quero, de forma alguma, mostrar o "embasamento psicológico" sobre o qual a obra foi concebida, atitude esta que iria totalmente contra as premissas de Bachelard para uma análise fenomenológica do filme. Quero apenas mostrar um pouco do caráter "familiar" deste filme, o que pode nos servir de entrada à casa onírica descrita por Bachelard. O que tem de ser trabalhado é a concepção de um espaço, como percebemos na primeira frase citada, mas acredito que este penetrar na infância e, conseqüentemente, na casa onírica da infância, também pode ter entrada a partir da ligação com os pais.

Lanço-me à descrição de aspectos do filme, com a finalidade de que o leitor tenha condições de localizar melhor momentos fundamentais do relato. Devo ressaltar também meu intuito de fixar as relações dos aspectos por mim descritos, com a teoria do espaço poético bachelardiano, com a qual trabalharei mais detidamente. 


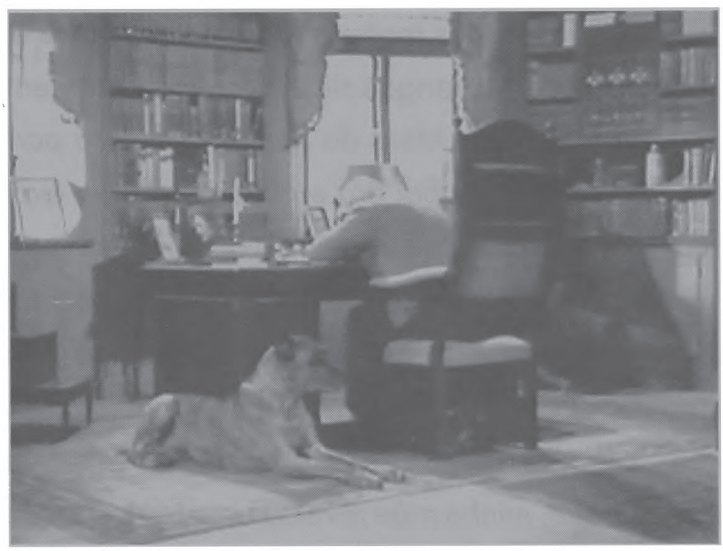

O filme começa com Isak Borg (Is = gelo e Borg = fortaleza Bergman, 1996 , p. 20), o protagonista, sentado em seu escritório com um cão a seu lado. É interessante notar que muitos personagens solitários nos filmes são acompanhados por seus cachorros. Tomo como exemplo o personagem-título Stalker, do filme de Tarkovski, em que o cão, além de companheiro, é um guia.

É de se lembrar a este respeito que o Deus Hermes muitas vezes aparecia na terra em forma de cachorro, e que também, ao longo de minhas viagens por vários países americanos e europeus, encontrei muitos junkies, viciados em drogas, que andavam, em sua extrema solidão, sempre acompanhados por um cão fiel, usualmente um pastor alemão. Voltando ao filme. O professor Borg escreve, ouvimos ao fundo sua voz interior - "O ser não se vê. Talvez se escute" (Bachelard, 1989, p. 21 8):
Nossas relações com outras pessoas consistem em discutir e avaliar seus caráteres e comportamentós. Foi isso que me fez afastar por minha vontade própria de praticamente todas as formas da dita vida social. Minha vida diária era cheia de trabalho duro, e sou grato por isso (ele acende um cigarro). Ganhara

Significação $13 \cdot 52$ 


\section{vida começou como um trabalho e acabou como amor pela ciência. \\ É encerrado em sua solidão que o ser de paixão prepara suas explosões ou seus feitos (BACHELARD, 1989, p. 29).}

A partir daí, a câmera começa a percorrer a sala, mostrando portaretratos com fotos dos parentes de Borg, que faz pequenos comentários sobre cada um. Uma belíssima forma, cinematograficamente perfeita, de nos introduzir no mundo interior e exterior do personagem.

Em continuação, a governanta vem chamá-lo para almoçar, continuam os diálogos internos.

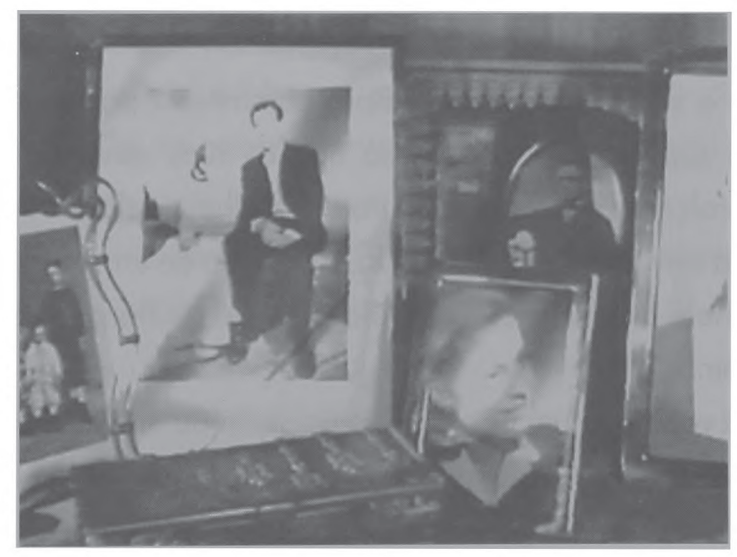

"Tenho sorte de ter uma boa empregada, sou um velho muito meticuloso, o que tornou minha vida bastante penosa. Amanhã receberei o prêmio de professor honorário da universidade de Lund..." Começam os letreiros.

Inicia-se o primeiro sonho (ainda não os devaneios) que o professor tem ao longo do filme. Isak dorme e ouvimos uma voz ao fundo: "Naquele domingo do dia dois de junho - "Mais urgente que as determinações 

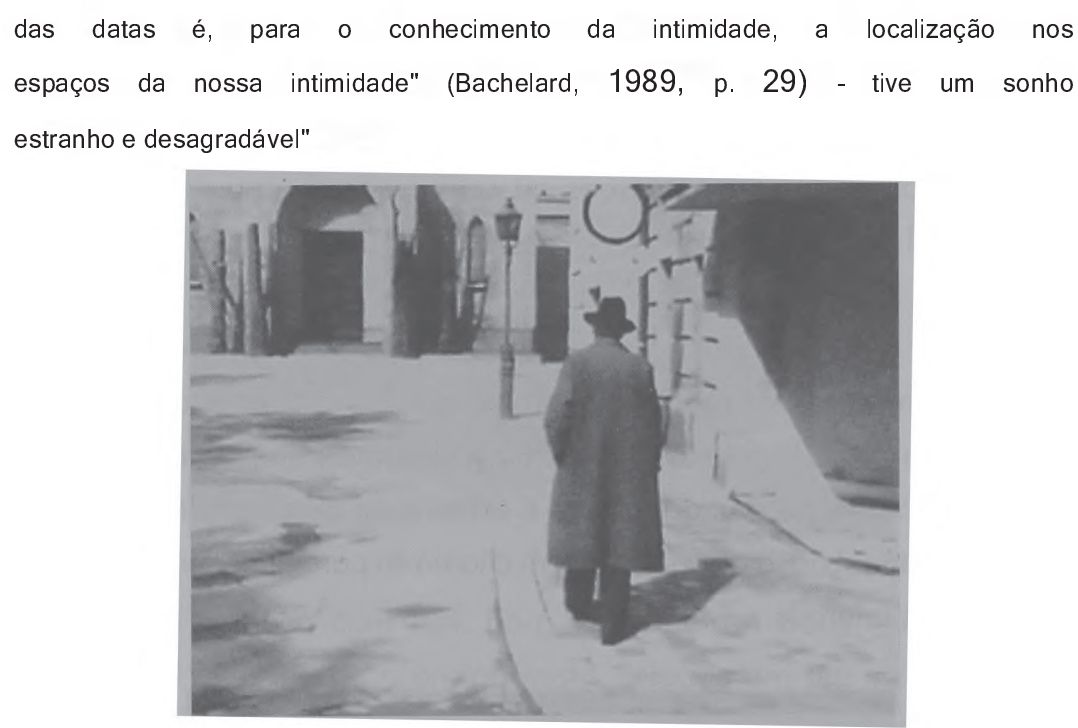

Durante o sonho, o professor Borg caminhava por um local desconhecido da sua própria cidade, só que as ruas estavam desertas. O relógio da calçada não tem ponteiros, ele olha o relógio de pulso, que também está sem ponteiros. Ao fundo, o barulho de um coração pulsando bastante forte e alto. Close no rosto assustado de Borg, o som pára. Ele volta a caminhar.

Dá meia volta e vê um homem de costas, anda em direção ao homem e o vira. O homem não tem rosto, cai e vai sangrando até esvaziar. Badaladas do sino da igreja. Ele continua a caminhar. Uma carroça puxada por dois cavalos vem em sua direção, uma das rodas se prende em um poste da calçada, até que se desprende e vai de encontro ao professor.

Os cavalos retomam o galope, no entanto, o caixão, que se encontrava dentro da carroça, cai. Uma mão aparece fora do caixão, Isak se aproxima, a mão o agarra, até que a tampa do ataúde se abre e vemos que quem está dentro do caixão é o próprio professor. O sonho acaba.

Significação $13 \quad 54$ 


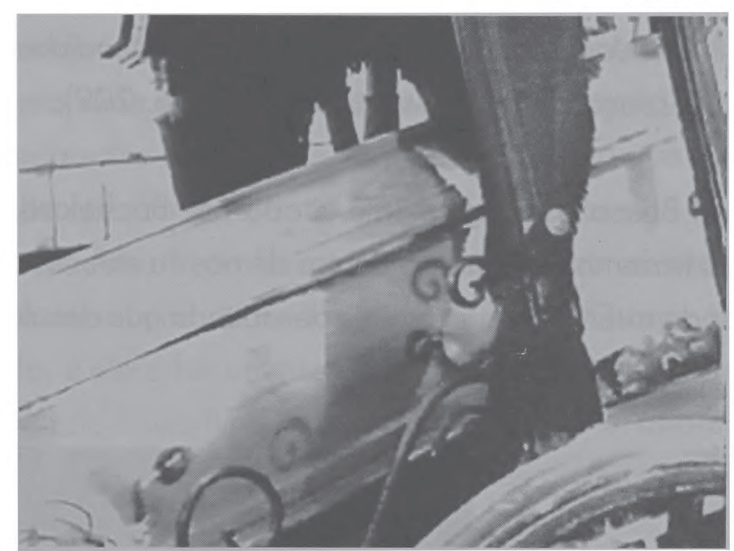

Embora a análise proposta por Bachelard esteja mais voltada para os devaneios do que para os sonhos, convém não esquecer que este sonho, criado por Bergman, é na verdade, dentro dos parâmetros bachelardianos, um devaneio do artista e não um sonho noturno. De qualquer forma, faremos apenas alguns apontamentos, pois esta ainda não é a parte do filme em que temos mais interesse em nos deter.

Dois aspectos me chamam a atenção. O caixão e as ruas desertas, dois espaços que podem levar os espíritos sonhadores às mais diversas regiões.

Este deserto, por mais que não seja o

deserto convencional, isto é, um deserto de areias escaldantes, oníricamente não deixa de nos remeterás grandes regiões de solidão [...] a imensidão do deserto vivido repercute numa intensidade do ser íntimo [...] todo esse universo que tem o signo do deserto está "anexado" ao espaço interior. Por essa anexação, a diversidade das imagens é unificada na profundidade "do espaço interior" Fórmula decisiva para a demonstração que quero fazer da correspondência entre 
a imensidade do espaço do mundo e a profundidade do "espaço interior"(BACHelARD, 1989. p. 209).

Para Henri Bosco constantemente citado por Bachelard, no deserto que por vezes trazemos escondido dentro de nós "a extensão da alma se perde através da extensão infinitamente desabitada que desola as solidões da terra" (BACHELARD, 1989, p. 209).

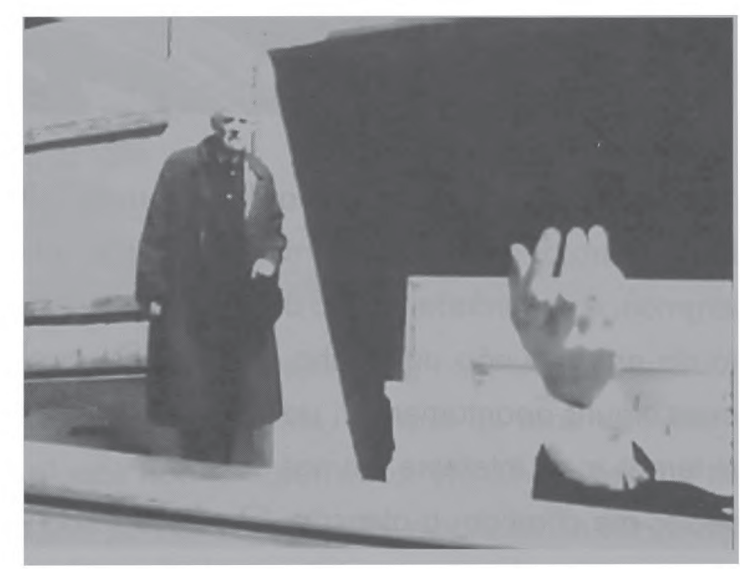

O caixão, assim como

- armário e suas prateleiras, a escrivaninha e suas gavetas, o cofre e seu fundo falso são verdadeiros órgãos da vida psicológica secreta. Sem esses "objetos" e alguns outros igualmente valorizados (como é o caso do caixão) -, nossa vida íntima não teria um modelo de intimidade. São objetos mistos, objetos-sujeitos. Têm, como nós, e para nós, uma intimidade (BACHELARD, 1989, p. 91).

Não é o caixão a morada dos dráculas, de mortos-vivos, o próprio sarcófago egípcio não está envolto em uma enormidade de mistérios?

Significação $13 \cdot 56$ 
Este caixão, onde inicialmente vemos apenas uma mão para fora, é capaz de sugerir uma série de devaneios: quem será o morto que se mexe que Bergman resolve de maneira surpreendente -, o que aquele caixão estará fazendo ali no meio da rua, entre vários outros?

Após o pesadelo, o professor Borg acorda sobressaltado e decide que não irá mais a Lund de avião, e sim de carro. Chama a governanta para ajudá-lo, e ela o faz um tanto quanto contrariada. Durante o café, a nora, esposa do único filho do professor, Marianne, aparece na sala e pergunta se pode ir com ele de carro. Surpreso, ele responde que sim. Dá-se início à viagem.

Primeiro os dois passam pela cidade (Estocolmo), que deve ser a dos sonhos de Isak, só que agora ela está cheia, com carros, bicicletas, pedestres, badaladas. Logo em seguida, já estamos na estrada.

A primeira conversa entre o professor e Marianne não é muito amena Marianne diz que não gosta dele, pois embora fosse chamado de um grande bem feitor da humanidade, era um egoísta; que quando ela havia Ihe pedido para ficar em sua casa por alguns dias, ele the havia respondido que não respeitava os sofrimentos de uma alma, e que se ela fosse se queixar, não o fizesse a ele, e sim a um padre ou um psicanalista que estavam muito em moda. Isak fica um tanto chocado consigo mesmo e tenta contar a ela seu sonho. Marianne responde: " " Não me interesso por sonhos"

A viagem prossegue e o professor faz um pequeno desvio: quer passar pela casa em que passou seus verões até completar 20 anos. "Esse signo da volta marca infinitos devaneios, pois regressos humanos acontecem de acordo com o grande ritmo da vida humana, ritmo que atravessa os anos, que luta pelo sonho contra todas as ausências" (BACHELARD, 1989, p. 111 ).

Chegam ao local, Marianne vai até o lago para se banhar e o professor fica sozinho, vai até o canteiro de morangos silvestres e os cheira. "É possível que eu tenha ficado meio sentimental, talvez estivesse cansado 
ou meio melancólico, foi então que vi que pensava em coisas ligadas à minha infância" (neste exato momento, com um corte seco, temos a visão da casa - primeiros indícios da casa como orientadora de devaneios). "É pelo espaço, é no espaço que encontramos os belos fósseis de duração concretizados por longas permanências. O inconsciente permanece nos locais" (BACHELARD, 1989, p. 29). "Não sei como isso aconteceu, a claridade do dia inundou a claridade maior das muitas lembranças que passaram por meus olhos com a força de eventos atuais" Neste instante começa o devaneio, cortes de imagens vão nos mostrando: primeiro uma árvore que balança; depois nuvens e finalmente os morangos silvestres.

Vale a pena interromper por alguns momentos minhas descrições do relato para observarmos, um pouco mais a fundo, como Bergman irá nos conduzir para o mundo dos devaneios. Em primeiro lugar ele nos mostra a casa, logo no instante em que Isak percebe que está começando a se recordar de sua infância

para o sonhador do lar, um âmbito imemorial se abre para além da mais antiga memória. A casa, como o fogo, como a água, nos permitirá evocar [...] luzes fugidias de devaneios que iluminam a síntese imemorial da lembrança (Bergman também se refere à claridade). Nessa região longínqua, memória e imaginação não se deixam dissociar (como veremos mais à frente nas lembranças imaginárias de (sak). Ambas trabalham para seu aprofundamento mútuo. Ambas constituem, na ordem dos valores, uma união da lembrança com a imagem. Assim, a casa não vive somente no dia-a-dia, no curso de uma história, na narrativa de nossa história. Pelo sonho, as diversas moradas de nossa vida se interpenetram e guardam 
os tesouros dos dias antigos" (BACHELARD, 1989,

p. 25).

"A casa, mais ainda que a paisagem, é um estado de alma" (BACHELARD, 1989, p. 84). Depois Bergman nos mostra a imagem de uma árvore
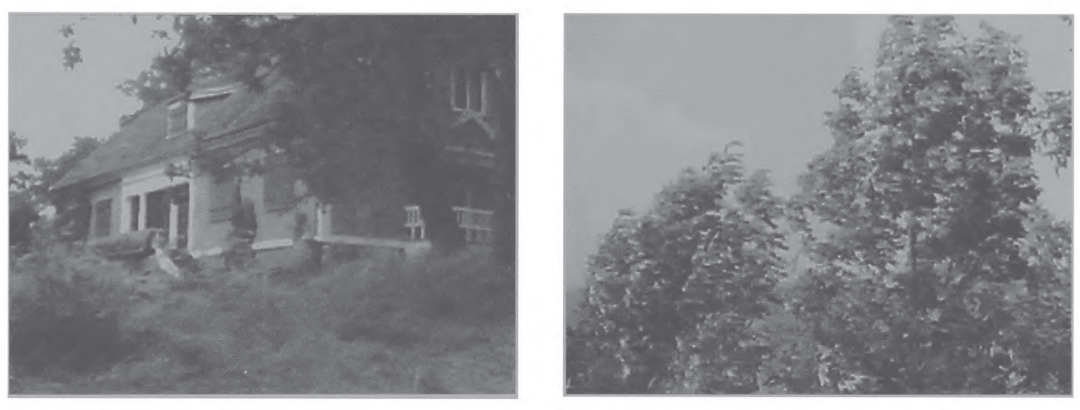

a árvore e seu sonhador, juntos, ordenam-se, crescem. No mundo do sonho a árvore nunca se estabelece como um ser acabado. Ela busca a sua alma. (citando Jules Supervielle) Uma longa árvore fremente sempre toca a alma, a árvore tem sempre um destino de grandeza.

Este destino, ela o propaga. A árvore faz crescer aquilo que a rodeia. Se assim podemos dizer, os dois espaços, o espaço íntimo e o espaço exterior, vêm constantemente estimular um ao outro em seu crescimento (BACHELARD, 1989, p. 205).

O terceiro elemento são as nuvens. "Diante desse mundo de formas mutáveis, em que a vontade de ver, superando a passividade da visão, projeta os seres mais simplificados, o sonhador é mestre e profeta. É o profeta do minuto" (BACHELARD, 1990) "[...] o devaneio da nuvem não é 
inteiramente analisado pela contemplação das formas. O devaneio da nuvem é uma participação mais profunda; atribui à nuvem uma matéria de doçura ou de ameaça, um poder de ação ou um poder de supressão da paz" (BACHELARD, 1990, p. 198).

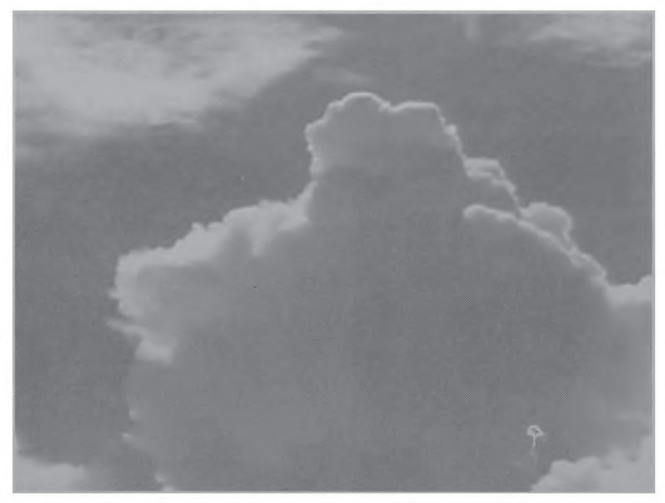

Por fim, antes do início do devaneio propriamente filmado, temos novamente a imagem dos morangos silvestres, que tanto lembram, na visão do personagem, a sua infância e que também são responsáveis pelo início do devaneio. Bachelard escreve, citando Milosz:

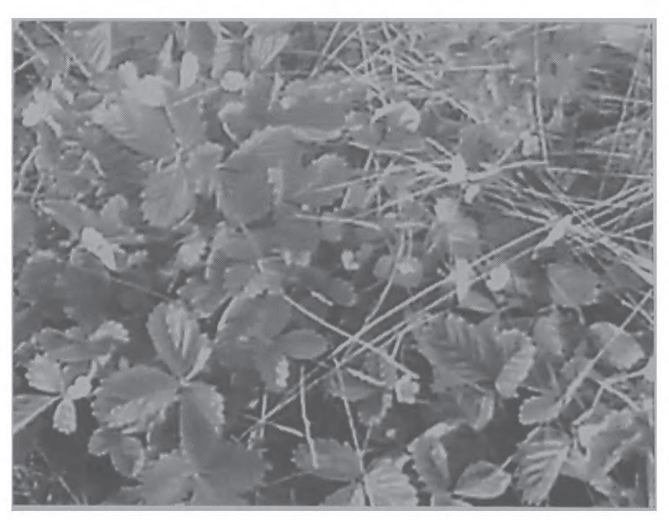

"Eu contemplava o jardim de maravilhas do espaço com o sentimento de olhar o mais profundo, o mais secreto de mim mesmo" (BACHELARD,

Significação $13 \quad 60$ 
1989, p. 194). Mas não podemos esquecer, levando em conta a afetividade que tais morangos despertam, que

o espaço vivido como um espaço afetivo, não desce entretanto à raiz dos sonhos da espacialidade. $O$ poeta vai mais fundo, descobrindo com o espaço poético um espaço que não nos encerra numa afetividade. Qualquer que seja a afetividade que matize um espaço, mesmo que seja triste ou pesada, assim que é expressa, a tristeza se modera, o peso se alivia (Bachelard, 1989, p. 206).

Assim sendo, o professor Borg começa a devanear ainda como velho (ele é um senhor de 78 anos)... "Isak revit une scène, qui a eu, dans son passé, une extrême importance, mais à laquelle il n'avait pas assisté" (SICUER, 1960, p. 143). Ele vê seus primos de infância como eram naquela época e presencia cenas, que em sua vivência cotidiana, não havia visto. Tenta dizer algo, mas seus personagens não o escutam. Reencontra Sara, sua prima com a qual iria se casar, mas que acabara por escolher seu irmão Sigfrid. Isak ouve as dúvidas e os sentimentos da prima - aqui temos um exemplo do bachelardiano "misto funcional de imaginação e memória" (BACHELARD, 1989, p. 34).

Subitamente ele é acordado por uma jovem, que vem lhe pedir carona. Tal jovem também se chama Sara e é desempenhada pela mesma atriz da Sara da juventude, Bibi Anderson. Junto a ela outros dois jovens, Victor e

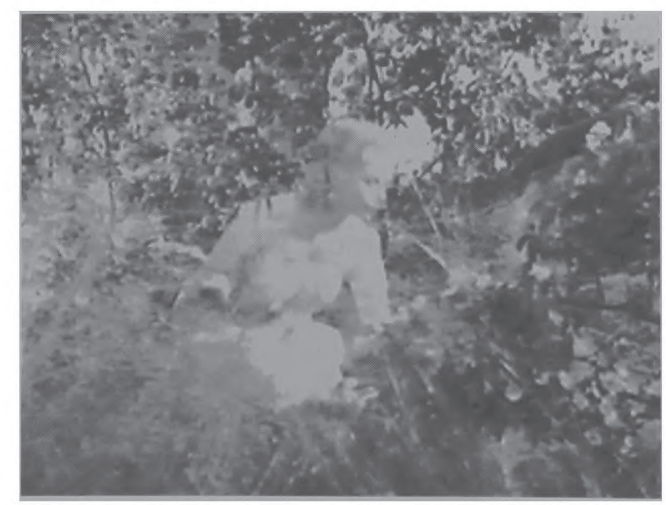


Anders, que são seus amigos-namorados (ou algo que valha), apanham carona e a viagem reinicia.

Todos conversam, até que um outro carro vem em direção a eles e ocorre um acidente. O casal do outro automóvel são Sr. e Sra. Altman, que acabam também pegando carona com os cinco, uma vez que o veículo deles não conseguiu funcionar após o acidente. Estes, no entanto, logo são expulsos por Marianne do carro, por discutirem de forma extremamente repugnante. Mais à frente, este casal entrará em um dos sonhos de lsak.

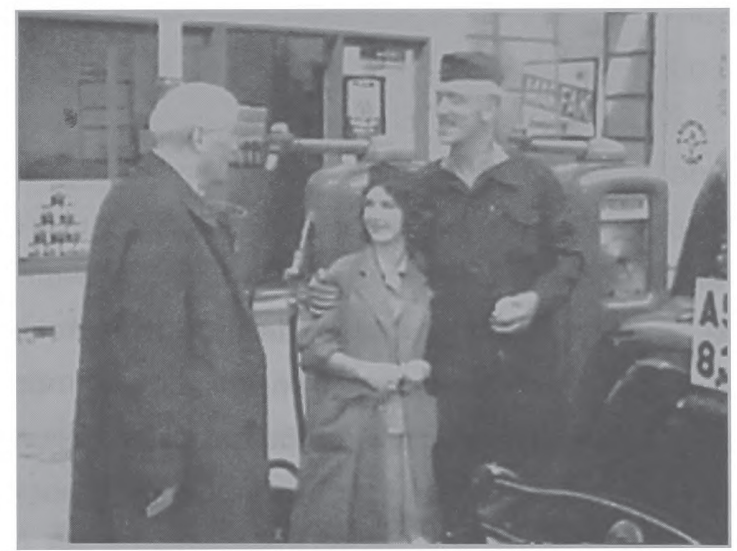

A viagem prossegue, eles param em um posto para abastecer. Lá, o frentista (o ator Max von Sydow, protagonista de O sétimo selo) oferece a gasolina por consideração ao professor, que muito fez pela cidade. Em seguida, todos param para o almoço.

A cidade é a cidade natal de Isak, onde mora sua mãe (e onde já morara sua avó, "a maior casa da cidade"), a verdadeira casa da infância de nosso protagonista. "A infância é certamente maior que a realidade" (BACHELARD, 1989, p. 35). Bergman escreve:

Sou muito atraído por minha infância. São imagens,

impressões claras e sensiveis. Às vezes, posso per-

Significação $13 \quad 62$ 
correr a paisagem de minha infância, os quartos, os móveis, os quadros da parede, a luz. É como um filme, pedaços de filmes. Posso reconstruir até o odor. Muitos artistas assemelham-se a meninos grandes. Tomemos Picasso, por exemplo, há um rosto de criança. Churchill é a mesma coisa. Stravinski, Orson Welles, Hindemith. Poderíamos também citar Mozart: certo, não conhecemos exatamente seu rosto, mas pelos quadros, podemos dizer que é um menino grande; e o rosto de Beethoven é o de uma criança zangada. Tomo consciência disso, quando entro no local das filmagens, ou quando estou com uma câmera entre as mãos e os técnicos em torno de mim. Então digo para mim mesmo: "Venham, nós vamos começar uma brincadeira" Me lembro exatamente quando eu era pequeno, tirava, um por um, meus brinquedos do armário antes de brincar. Tenho a mesma impressão num local de filmagens. Há uma certa analogia. Só que, por uma razão inexplicável, hoje, me pagam para organizar a brincadeira, certas pessoas me respeitam, elas seguem minhas instruções, o que

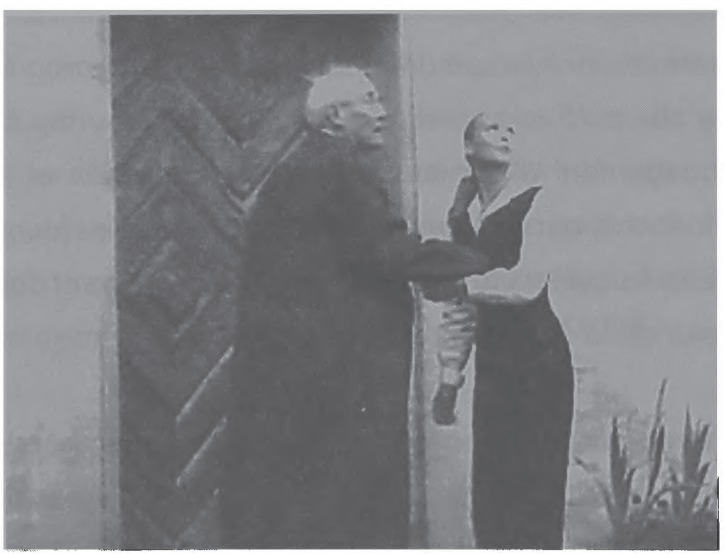


não deixa de me emocionar de tempos em tempos (LOPES, 1988, p. 331).

Isak vai visitar sua mãe e Marianne o acompanha.

Mas, se voltarmos à velha casa depois de décadas de odisséia, ficaremos muito surpresos de que os gestos mais delicados, os gestos iniciais, subitamente estejam vivos, ainda perfeitos. Em suma, a casa natal gravou em nós a hierarquia das diversas funções de habitar (BACHELARD, 1989, p. 34).

Logo ao chegarem à porta, ouvimos um barulho de trovoada, ouvese também o barulho de pássaros sobrevoando.

Lorsqu'ils arrivent à la porte de la maison, un coup de tonnerre annonce un orage proche. En fait, à cet instant, la lumière baisse, devient comme sulfureuse, inquiétante. Par ce changement sensible d'eclairage, légitimé sur le plan de la réalité par la montée de l'orage, Bergman cherche à traduire un changement d'atmosphère avant l'entrée en scène de la vieille femme, dont on sait déjà par le propos du garagiste qu'elle a 95 ans et vit seule dans un coin perdu. Un changement d'état aussi dans l'esprit d'sak et de Marianne, qui viennent de se détendre avec les jeunes gens. Ils quittent le domaine de la vie. Ils entrent dans celui de la Mort (SICLIER, 1960, p. 147).

Além da tempestade, Bergman também se utiliza dos pássaros para antecipar esta atmosfera tenebrosa (veremos em outras cenas mais à frente).

Significação $13 \cdot 64$ 


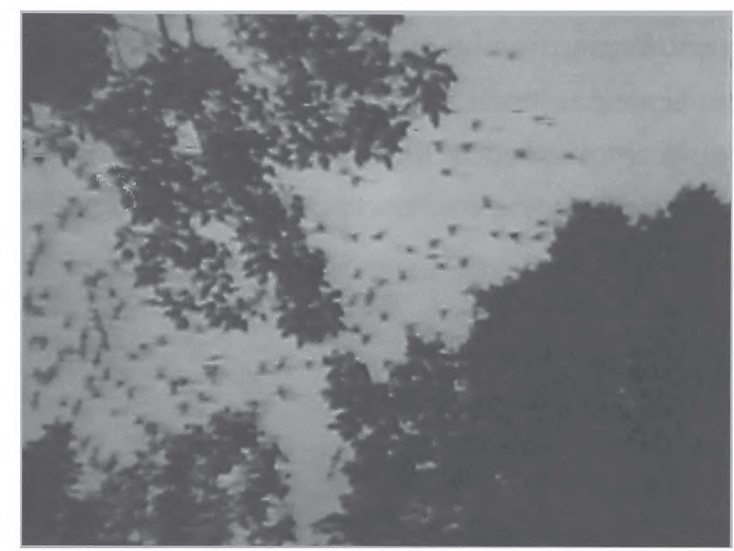

Em seu filme anterior a este, O sétimo selo, Bergman vai tratar da morte, e logo na primeira cena do filme temos: nuvens, música e um pássaro.

Os pássaros sempre tiveram para mim algo de demoníaco, de misterioso e de perigoso. Tenho e sempre tive medo dos pássaros. Desde a minha infância. Se um pássaro entra numa sala onde me encontro, abandono o local terrificado. Depois o pobre pássaro desembaraça-se o melhor que pode. No melhor dos casos pode ser que Ihe abra a janela. No verão passado aconteceu que alguns pássaros bateram contra as vidraças da casa onde eu me encontrava, em Farö. Uma das salas é envidraçada de dois lados e, estando as janelas iluminadas, os pássaros em vôo esbarravam nos vidros e caíam no solo. Mas eu nunca me teria aproximado para Ihes tocar. Não ousaria fazê-lo. Há demasiado tempo os receio (WILDE, 1969).

Isak e Marianne entram na casa; a velha, após haver estranhado Marianne, confundindo-a com Karin, a esposa morta de Isak, a deixa 
entrar, e lhe pede que apanhe sua "caixa de memórias" Nessa caixa estão os mais variados tipos de objetos, porta-retratos, boneca (que Marianne segura entre as mãos, alusão ao filho que carrega na barriga), livros, um relógio, idêntico ao sonhado por Isak: um relógio sem ponteiros,

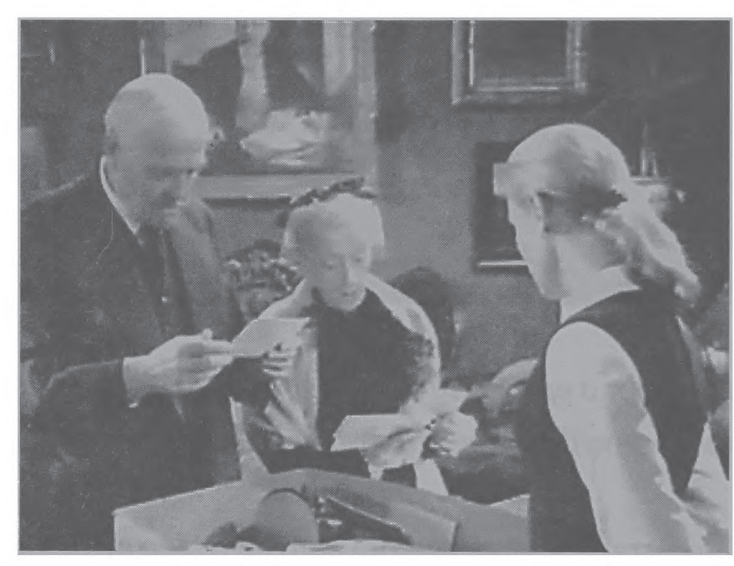

que ela irá dar de presente a um de seus netos. Na caixa da mãe de Isak, assim como nos cofres

estão as coisas inesquecíveis; inesquecíveis para nós, mas também para aqueles a quem daremos os nossos tesouros. $O$ passado, o presente e o futuro nele se condensam. E assim o cofre (e esta caixa) é a memória do imemorial. No momento em que o cofre se abre não há mais dialética. O exterior é riscado com um traço; tudo é novidade, tudo é surpresa, tudo é desconhecido. O exterior já nada significa. E até, supremo paradoxo, as dimensões do volume não-têm mais sentido porque uma nova dimensão acaba de se abrir: a dimensão da intimidade (BACHEIARD, 1989, p. 97-8).

Significação $13 \cdot 66$ 
Marianne e o professor Borg voltam ao carro, onde apenas Sara se encontra, os dois jovens pelejam ao discutirem sobre Deus e Ciência. Marianne vai buscá-los e a viagem reinicia. Isak adormece e recomeçam seus sonhos. "Dormi, mas fui atormentado por sonhos e aparições que me pareciam muito tangíveis e humilhantes, mas não posso negar que havia imagens poderosas, que entravam em minha consciência com determinação."

O sonho se inicia com uma enorme quantidade de pássaros sobrevoando o céu, o que já nos antecipa um pesadelo. Primeiro Isak reencontra com Sara (de sua juventude). Por fim acaba vendo-a entrar na casa onde se encontra com o irmão de Isak, seu marido. Esta casa termina por se transformarem um tribunal onde a competência profissional de Isak será posta à prova. Ele falha em todos os exames, exames estes que são feitos pelo Sr. Altman. Depois ambos vão até o lado de fora da casa - a cena,

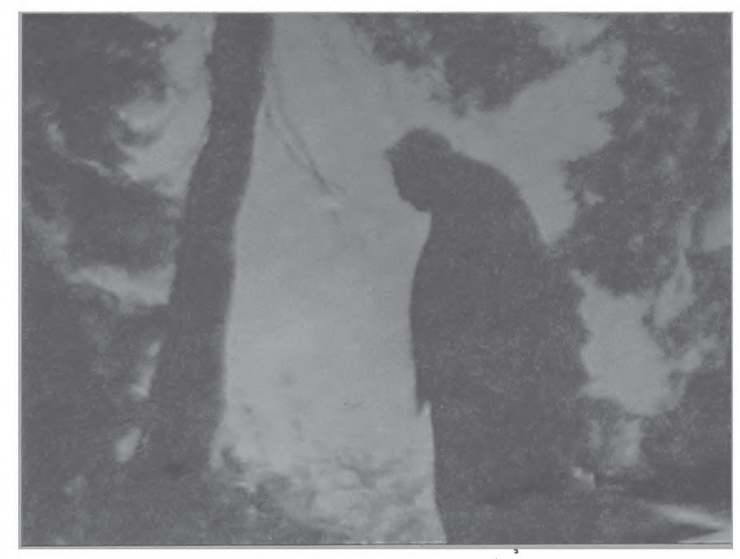

maravilhosamente - não encontro palavra mais adequada - construída, é feita de modo que acompanhamos o andar deles através do reflexo da água de um lago "[...] o lago é o próprio olho da paisagem, o reflexo sobre as águas é a primeira visão que o universo tem de si mesmo, a maior beleza de uma paisagem refletida é a própria raiz do narcisismo cósmico" (BACHELARD, 1989, p. 213) - onde podem observar um bosque. 
Ouvimos alguns risos, é a esposa de Isak, morta há trinta anos, quem aparece. Por trás dela, surge um homem que a beija no pescoço. Karin começa a olhar-se em um pequeno espelho que tem em suas mãos.

Os espelhos de vidro [...] dão uma imagem por demais estável. Tornarão a ser vivos e naturais quando pudermos compará-los à água viva e natural, quando a imaginação renaturalizada puder receber a participação dos espetáculos da fonte do rio. Percebemos aqui um dos elementos do sonho natural, a necessidade que o sonho tem de inserir-se profundamente na natureza. Não se sonha

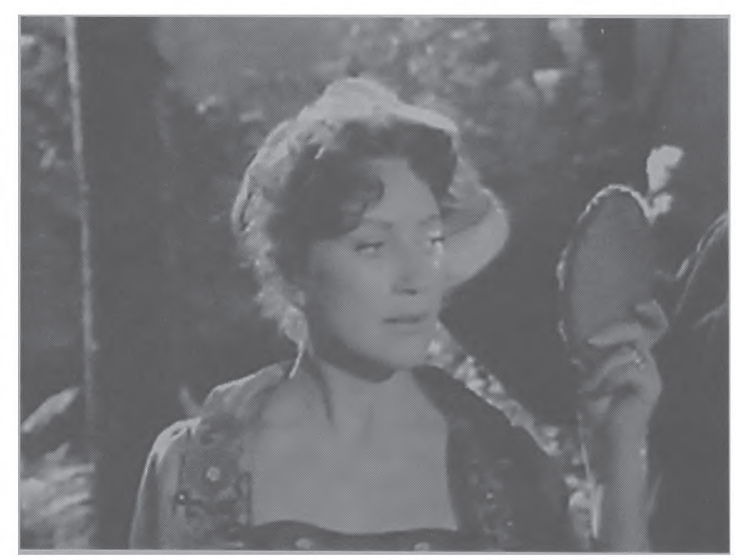

profundamente com objetos. Para sonhar profundamente, cumpre sonhar com matérias. Um poeta que começa pelo espelho deve chegar à água da fonte se quiser transmitir sua experiência poética completa. A nosso ver, a experiência poética deve ser posta sob a dependência da experiência onírica (BACHEIARD, 1989a, p. 24).

Significação $13 \cdot 68$ 
- creio que nosso poeta Bergman antecipou as águas da fonte para poder reutilizá-las em forma de espelho.

O homem se aproxima de Karin e percebemos o que irá acontecer. Borg nunca teve certeza de que Evald era realmente seu filho. Depois da insinuação, Karin e o amante desaparecem. O Sr. Altman diz a pena do professor: Solidão.

Isak acorda e percebe que adormecera no carro. Olha para Marianne. Os três jovens estão no campo apanhando flores para o professor, pois querem homenageá-lo pela condecoração de Professor Honorário. Ele diz: "Nestes últimos meses tenho tido sonhos estranhos, absurdos, é como se quisessem me dizer algo que não quero ouvir acordado. Que estou morto apesar de vivo" Mariane diz que Evald, filho de Isak, fala exatamente a mesma coisa - sobre estar morto apesar de vivo - e Ihe conta o que aconteceu quando ela disse ao marido que estava grávida.

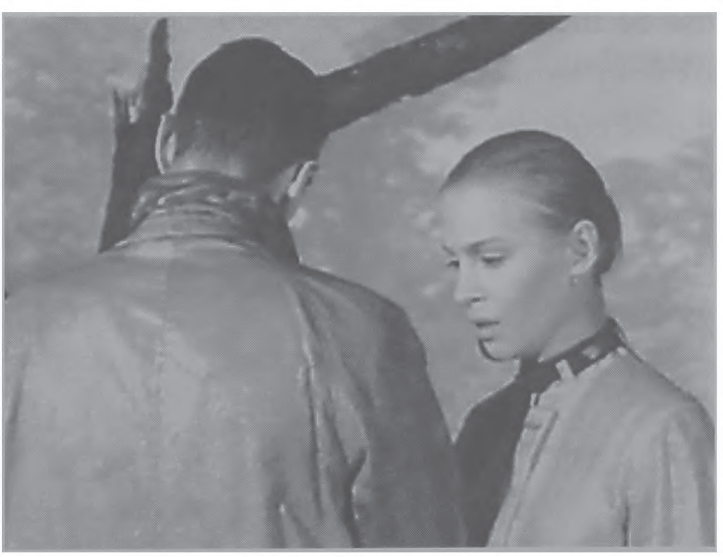

Na cena contada por Marianne, que é mostrada ao espectador, ela leva Evald até uma praia deserta, chove. Depois que, dentro do carro, conta sobre o filho, ele sai. Ela vai atrás dele, os dois são posicionados em frente a uma árvore que tem sua parte superior quebrada. $\mathrm{O}$ marido não quer o filho, não quer deixar aquela vida se expandir, crescer, como já havíamos citado, "a árvore e seu sonhador, juntos, ordenam-se, 
crescem." E ainda em Bachelard, referindo-se à árvore, "Dar espaço poético a um objeto é dar-Ihe mais espaço do que aquele que ele tem objetivamente, ou melhor dizendo, é seguir a expansão de seu espaço íntimo" (BACHELARD, 1989, p. 206). Não seria uma ótima forma de mostrar este não-querer-expansão utilizar-se de uma árvore quebrada, que não se dirige aos céus?

A viagem recomeça e eles finalmente chegam a Lund. É dia da homenagem. Bem resumidamente, depois da cerimônia, o professor volta à casa do filho (que mora nesta cidade) e vai dormir, suas últimas palavras são: "Quando me sinto ansioso ou triste durante o dia, tento relaxar com as lembranças de minha infância. Foi isso que fiz esta noite" Ele começa a sonhar com Sara que mostra a ele onde estão seus pais.

A cena final de.Morangos silvestres contém uma forte dose de saudade e nostalgia: Sara toma a mão de Isak Borg levando-o para uma clareira na floresta, na qual bate sol. Do outro lado do canal ele pode avistar seus pais, que Ihe acenam (BERGMAN, 1996,

P- 20).

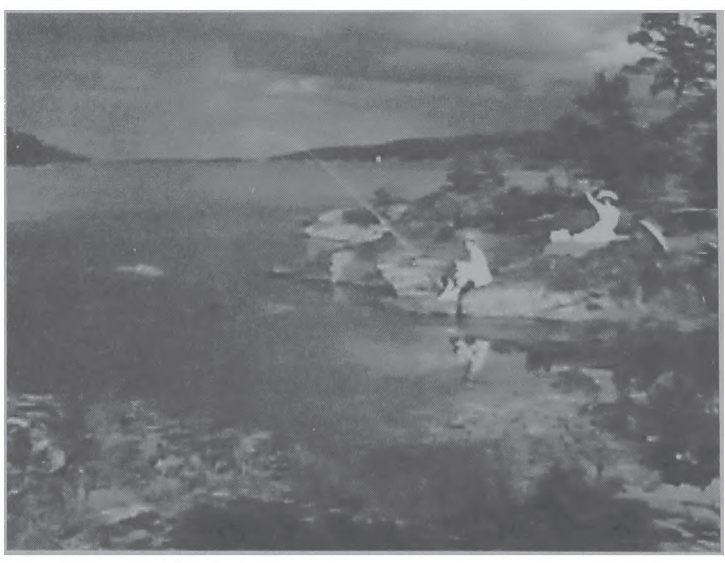

Significação $13 \quad 70$ 


\title{
Considerações Finais
}

\author{
Não quero o silêncio surdo, \\ quero um silêncio de ouvidos aguçados, \\ absolutos, não quero confundir nenhuma nota \\ quando o silêncio entoar sua lira...
}

Faço a seguir algumas considerações finais, uma vez que uma conclusão seria algo não condizente com o compromisso assumido por mim no início deste artigo. Escrever conclusões, parece-me algo como dar uma interpretação final a tudo o que foi dito anteriormente, o que seria colocar-me numa atitude antibachelardiana, e também antibergmaniana, se assim podemos dizer.
O que comunicamos aos outros não passa de uma orientação para o segredo, sem, contudo, jamais podê-lo dizer objetivamente. O segredo nunca tem uma objetividade total. Neste caminho, orientamos o onirismo, mas não o concluímos (BACHELARD, 1989. p. 32).

Além disso, o que tentei fazer, neste artigo, não foi desvendar ás intenções de Bergman ao realizar o filme, tentei apenas, a partir da poética do espaço de Bachelard, abrir algumas possibilidades de percepção que, de algum modo, conduzam até à poesia dos devaneios de Bergman. De Bergman, que também não entende as interpretações que muitos fazem a respeito de seus filmes.

As pessoas te fazem belos desenhos, com linhas claras à direita e à esquerda e depois vêm te dizer:

"Ah, eu entendo, nesta cena, você quis dizer isso e 
aquilo, é evidente e pode ser relacionado com..."

Isso me paralisa completamente. Não sei mais o que dizer. Vejam que talvez vocês tenham razão! É possível. Não digo isso a vocês para me proteger ou para desviar a questão, não! É simplesmente porque os temas dos quais vocês me falam não se apresentam absolutamente da mesma forma para mim (BJÖRKMAN, 1978, p. 203).

Diante da narrativa do filme, entendida como um processo em que se integram ações, personagens e maneiras de contar, quis tão-somente registrar uma tentativa de aproximação que nasce em mim a partir da fascinante mundividência de Bachelard, "Pois é preciso também dar um destino exterior ao seu interior" (BACHELARD, 1989, p. 30).

\section{Bibliografia}

BACHELARD, G. 1985. O direito de sonhar. São Paulo: Difel. . 1989. A poética do espaço. São Paulo: Martins Fontes. 1989a. A água e os sonhos. São Paulo: Martins Fontes. 1990. O ar e os sonhos. São Paulo: Martins Fontes.

Bergman, 1.1996. Imagens. São Paulo: Martins Fontes.

BJORKMAN, S., MANNS, T. e SIMA, J. 1978. O cinema segundo Bergman. Rio de Janeiro: Editora Paz e Terra.

Lopes, C. A. M. 1988. O planeta Bergman. Belo Horizonte: Oficina de livros.

SICUER, J. 1960. Ingmar Bergman. Paris: Editions Universitaires.

WILDE, O. 1972. O retrato de Dorian Gray. Rio de Janeiro: Abril Cultural. 1969 Coletânea de entrevistas agrupadas no livro Cinema sueco. Lisboa: Publicações Dom Quixote.

Significação $13 \quad 72$ 


\section{Ficha Técnica}

Filme: Morangos silvestres

Título Original: Smultronstället

Produção, distribuição: Svensk Filmindustri

Direção e Roteiro: Ingmar Bergman.

Diretor de produção: Allan Ekelund

Fotografia: Gunnar Fischer

Música: Erik Nordgren

Cenografia: Gittan Gustafsson

Montagem: Oscar Rosander

Estréia: 26/12/1957 Nos cinemas Roda Kvarn e Fontãn

Duração: 91 minutos

Atores: Victor Sjöström (Isak Borg), Bibi Anderson (Sara), Ingrid Thulin (Marianne), Gunnar Björstrand (Evald), Folke Sundquist (Anders), Björn Bjelfvenstam (Viktor), Naima Wifstrand (a mãe de Isak), Julian Kindahl (Agda), Gunnar Sjöberg (Sr. Altman), Gunnel Broström (Sra. Altman), Gertrud Fridh (Karin), Ake Fridell (o amante de Karin), Max von Sydow (frentista, Akerman), Sif Ruud (a tia), Yngve Nordwall (tio Aron), Per Sjöstrand (Sigfrid), Gio Petré (Sigbritt), Gunnel Lindblom (Charlotta), Maud Hansson (Angelica), Lena Bergman (Kristina), Per Skogsberg (Hagbart), Göran Lundquist (Benjamin), Eva Norée (Anna), Monica Ehrling (Brigitta), Ann-Mari Wiman (Eva Akerman), Vendela Rudbäck (Elisabeth), Heide Wulff (reitor). 